\title{
HRM Practices and Employee Retention in Thailand-A Literature Review
}

\author{
Sorasak Tangthong, Jirasek Trimetsoontorn, and Nutthawut Rojniruntikul
}

\begin{abstract}
An empirical study is conducted to investigate the effects of HRM practices on employee retention in Thailand's FDI manufacturing industry. HRM practices that will be covered in this research consist of compensation \& benefits management and reward system, and training \& development. HR Intervening, which acts as the mediating variable, will be employee engagement. As the dependent variable and an observed variable, is employee retention. Thus, the conceptual model created for this study will comprise of two independent variables, one mediating variable and one dependent variable. A total of 5 theoretically-based hypotheses are developed, indicating possible positive and negative relationships among the variables of the model. Input consists of 400 top management, human resources managers/leaders and line managers of Thailand FDI's key industrial zone in Rayong province. The proposed model is empirically tested by using AMOS of a Path Analysis modeling approach. It is hoped that this study will help both academics and those managing human resource to realize, understand and see the influence of HRM practices and employee retention.
\end{abstract}

Index Terms-Employee retention, human resource management (HRM) practices, Thailand's manufacturing industry.

\section{INTRODUCTION}

HRM practices are essential for firm performance. Firms have used human resource practices to achieve their performance, particularly in relation to retention. The impact that human resource practices have on firm performance are apparent, as many researchers have shown in their studies from the United States and Europe [1], [2] to Asia [3], [4] and Africa [5]. Human resource management practices consist of many policies and practices that are used by managers to recruit, select, develop, utilize, reward, and maximize the potential of human resources in organizations [6]. They have been studied extensively by researchers, but the ones that have a significant effect on firm performance are compensation \& benefits management and reward system, and training \& development [7], [8]. These are considered by organizations to be important human resource practices for the following reasons. Compensation \& benefits management and reward system are needed in organizations for financial income and well-being of their employees. Employees' living status in society, satisfaction, loyalty, and productivity are influenced by compensation [9]. Employees

Manuscript received August 10, 2013; revised October 17, 2013.

Sorasak Tangthong, Jirasek Trimetsoontorn, and Nutthawut Rojniruntikul are with King Mongkut Institute of Technology Latkrabang, Pathumthanee 12150 Thailand (e-mail: sorasak@probizs.com, ktjirase@kmitl.ac.th, krnuttaw@kmitl.ac.th). need to be provided with training \& development to develop their skills and perform better at work. Training and development can lead to superior knowledge, skills, abilities, attitudes, and behavior of employees, thereby enhancing excellent financial and non-financial performance of the organizations [10]. As for firm performance, employee retention is chosen as the observed variable since previous studies have shown how it has been related to effectiveness as a human resource outcome [11]. While there have been many studies on the relationship between human resource practices and firm performance, there are also studies that have managed to identify other factors that could have an impact on the relationship between HRM practices and organizational performance [12]. These factors are the HR Intervening, which mediate the relationship between HRM practices and firm performance. Employee engagement is chosen as the HR Intervening in this study, so as to gain a better understanding of the nature and the impact that employee engagement has on compensation \& benefits management and reward system, and training \& development as the two HRM practices, and employee retention, as the observed variable of firm performance. Thus, by understanding the relationship between HRM practices and firm performance, it would serve as a platform for managers in organizations by assisting them to achieve better performance.

\section{LITERATURE REVIEW AND HYPOTHESES}

This section will focus on prior literature involving HRM practices and their interactions with employee engagement and employee retention as well as the literature surrounding the hypotheses that have been formulated for this study. It will focus, in particular, on the relationships between compensation \& benefits management and reward system, and training \& development as the two HRM practices, employee engagement as the HR Intervening and employee retention as the dependent variable. Study indicates potential hypothetical associations among these variables, which were derived after a systematic review of the theoretical and empirical literature on the HR-firm performance relationships. Altogether, 5 hypotheses were formulated, which are explained below.

\section{A. Human Resource Management System}

To understand the significance of HR and the way it is able to determine the performance outcome of organizations, the HR process must be viewed as a whole. Researchers have viewed organizations as systems [13], [14] and, as a result, it is important to consider the human resource inputs, processes 
(practices) and outputs that will lead to a sustained competitive advantage [15] in organizations. Thus, human resource has become a unique source for sustained competitive advantage [16] in organizations. The human resource system in an organization consists of the dynamic processes of $\mathrm{HR}$, such as the recruitment and selection, performance appraisals, training, and compensation. These allow the firm to acquire and develop its resources (inputs) to achieve high performance (outputs), and thereby having a competitive advantage. The human resource system model was developed by [13], outlining the various components of the human resource management system. The model is based on [17] resource-based view of the firm, consisting of variables that a person brings to the firm, such as skills and motivation [18], and the human resource processes, which include recruitment, selection, training, reward systems and performance management [19], [20]. These variables create products and services that will lead the firm towards a sustained competitive advantage. In other words, the inputs (skills and motivation) are converted through the human resource processes to achieve the outputs of job and firm performance [15].

\section{B. Firm Performance and Organizational Effectiveness}

Firm performance represents the final outcome of an effective HR system [15]. Organizational effectiveness is part of that construct and has been defined as the ability of organizations to produce desire results [21]. It can be used as measures of productivity, service quality and profitability [22]. These measurements were chosen in [22] because they would lead to a full examination of firm performance [23], [24]. In any case, researchers have used both financial and non-financial metrics to measure organizational performance [25]. Financial measures can be profit, sales, and market share. Non-financial measures can include productivity, quality, efficiency, as well as attitudinal and behavioural measures, which include commitment, intention to quit and satisfaction [26]. This study will focus on the latter.

\section{Human Resource Management Practices}

Using the HR system concept, human resource practice, which is the HR process part of the human resource management system [15], will be examined in this study. HR practices have been defined as a set of distinct yet interrelated activities, functions, and processes aimed at attracting, developing, and maintaining a firm's human resources [15]. They are viewed as independent variables in most studies that can have an impact on firm performance, which is the dependent variable [27]-[29]. They consist of many activities and policies aimed at carrying out the "people" or the human resource aspect of a management position [30]. This study will only focus on two practices, which are compensation \& benefits management and reward system, and training \& development. These practices are chosen because they are known to have the most impact on firm performance. Each of them will now be considered in turn.

\section{1) Compensation \& benefits and reward system}

Compensation refers to all forms of financial returns and tangible benefits that employee receives as part of the employment relationship [31]. Benefits are indirect financial and non-financial payments employees receive for continuing their employment with an organization [32]. Reward system is anything that is extrinsically or intrinsically reinforced, maintain and improve the employees' behavior in an organization [33]. Compensation is one of the main features used by organizations to attract and retain their most valuable and worthy assets [34]. It is known to have a positive relationship with employee retention [35]. Benefits are also positively related to retention [36]-[38]. Reward system can affect the performance of the employee and their desire to stay with the organization [39], [40]. Reward system also plays a vital role in employee engagement, which depends on staff feeling that they are fairly rewarded for their skills, knowledge and contribution [41]. Thus, we hypothesize that:

- $\mathrm{H}_{1}$ : Compensation \& Benefits and Reward System have a relationship with Employee Retention.

- $\mathrm{H}_{2}$ : Compensation \& Benefits and Reward System have a relationship with Employee Engagement.

\section{2) Training \& development}

Training \& development refers to a systematic development of the knowledge, skills and attitudes required by employees to perform adequately a given task or job [42]. It is regarded as the most common human resource practice [43]. When employees feel that training is available at all times, they will have a sense of emotional attachment and commitment to the organizations, and are thus less likely to leave their jobs [44]. [20] also suggested that training is an important determinant of employee retention. This is further supported by [36]-[38]. Furthermore, when managers provide opportunities for training and support regarding career development, they help create employee development and drive employee engagement [45]. From the above, we hypothesize that:

- $\mathrm{H}_{3}$ : Training \& Development have a relationship with Employee Retention.

- $\mathrm{H}_{4}$ : Training \& Development have a relationship with Employee Engagement.

\section{Employee Engagement}

Employee engagement is a feeling of positive emotions by employees toward their work, find their work to be personally meaningful, consider their workload to be manageable, and have hope about the future of their work [46]. To become fully engaged is to be involved in and enthusiastic about the work [47]. There are two aspects of employee engagement, which are cognitive engagement and emotional engagement/physical engagement. Cognitive engagement is the extent to which a worker is aware of their mission at work and their role in the organization. Emotional engagement/physical engagement is the extent to which the worker empathizes with others at work, and connects in a meaningful way with their co-worker [48]-[50]. According to previous studies, employee engagement has a positive effect on organizational performance outcomes, such as employee retention [51]. Thus, we hypothesize that:

- $\mathrm{H}_{5}$ : Employee Engagement has a relationship with Employee Retention. 


\section{RESEARCH FRAMEWORK}

Having reviewed the literature, it is possible to develop a comprehensive framework, presented in Fig. 1, consisting of HRM practices, which include Compensation \& Benefits Management and Reward System, and Training \& Development as the independent variables. Employee Engagement as the HR Intervening and firm performance, which has one observed variable of employee retention, as the dependent variable.

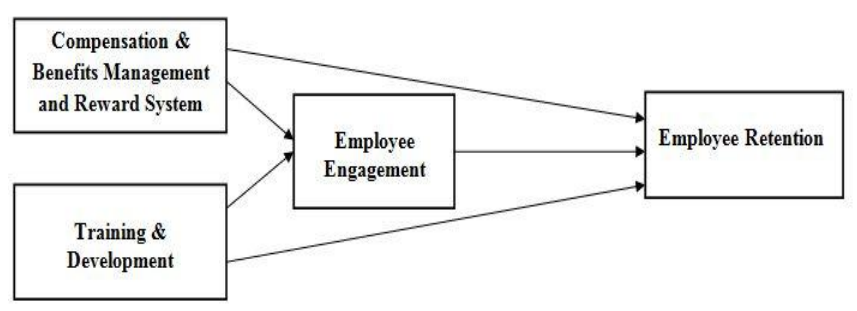

Fig. 1. Conceptual model.

\section{EXPECTED RESULT AND CONCLUSION}

The aim of this research was to carry out an empirical study on the effect of human resource management (HRM) practices on employee retention in Thailand's FDI manufacturing industry, focusing in particular on compensation \& benefits management and reward system, and training \& development. By reviewing the literature, studies have shown the significance of both HRM practices and the effect that they can have on employee retention, both directly and indirectly. In relation to the former, benefits and training are said to be positively related to retention because they motivate employees and "lock" them to their jobs [36]-[38]. Compensation and reward system are known to attract employees to stay with the organization [34], [35], [39], [40]. But despite the support for these two HRM practices, there is a caveat to one of them, namely training. While training can play a role to increase staff retention, it cannot address all of the factors that contribute to retention, such as excessive caseloads and promotional opportunities [35]. Thus, training will need to be accompanied by other HRM practices, such as compensation \& benefits management and reward system, which are considered to be more effective in retaining employees. Furthermore, from the review of the literature, compensation \& benefits management and reward system have more studies to support their relationship with employee retention, totaling seven, compared to training \& development with five studies. With more studies to support its relationship with employee retention, compensation is not only considered to be the return and benefits for the work done by employees, but it also reflects their accomplishments [52]. Employees will feel that they are appreciated by their organizations for their performance and contributions if they get good salary [53], and are thus more likely to stay with the organization. As for employee engagement, there is an equal amount of study to support its role as the HR Intervening. Reward system and training help encourage employee engagement [41], [45], which in turn has a positive effect on employee retention [51].
Therefore, to conclude, both compensation \& benefits management and reward system, and training \& development have a direct and indirect effect on employee retention, even if training \& development does not have a complete role in determining employee retention for direct effect. By reviewing the literature, their studies have shown that the two HRM practices, as a whole, do have a positive relationship with firm performance. But there are also other contexts, countries and industries. Researchers expect this to be an empirical study, specifically for Thailand's manufacturing industry, in particular FDI firms, where their positive relationships of firm performance with HR practices will provide a useful insight to all relevant academics. As for HR practitioners, the two key HR management practices, which are compensation \& benefits management and reward system, and training \& development, will be of continuing concern to their organizational performance.

\section{REFERENCES}

[1] P. Boselie, J. Paauwe, and P. G. W. Jansen, "Human resource management and performance: Lessons from the Netherlands," The International Journal of Human Resource Management, vol. 12, no. 7, pp. 1107-1125, 2001.

[2] K. Hoque, "Human resource management and performance in the UK hotel industry," British Journal of Industrial Relations, vol. 37, pp. 419-443, 1999.

[3] I. Björkman and F. Xiucheng, "Human resource management and performance of western firms in China," International Journal of Human Resource Management, vol. 13, pp. 853-864, 2002.

[4] H.-Y. Ngo, T. Daniel et al., "Human resource practices and firm performance of multinational corporations: Influences of country origin," International Journal of Human Resource Management, vol 9, pp. 632-652, 1998.

[5] F. Ghebregiorgis and L. Karsten, "Human resource management and performance in a developing country: The case of Eritrea," International Journal of Human Resource Management, vol. 18, no. 2, pp. 321-332, 2007

[6] L. C. Megginson, G. M. Franklin, and M. J. Byrd, Human Resource Management, Houston, TX: Dame Publications, 1995.

[7] C. Ichniowski, K. Shaw, and G. Prennushi, "The effects of human resource management practices on productivity: A study of steel finishing lines," American Economic Review, vol. 87, pp. 291-313, 1997.

[8] J. D. Shaw, J. E. Delery, G. D. J. Jenkins, and N. Gupta, "An organization-level analysis of voluntary and involuntary turnover," Academy of Management Journal, vol. 41, no. 5, pp. 511-525, 1998.

[9] K. Aswathappa, Human Resource Management: Text and Cases, Delhi: Tata McGraw-Hill Publishing Company Limited, 2008.

[10] N. N. Thang and D. Buyens, "What we know about relationship between training and firm performance: A review of literature," presented at the 7th International Conference on Ethics and Quality of Work-life for Sustainable Development, Bangkok, Thailand, 2008.

[11] P. K. Mahal, "HR practices as determinants of organizational commitment and employee retention," The IUP Journal of Management Research, vol. 11, no. 4, pp. 37-53, 2012.

[12] E. W. Morrison, "Organizational citizenship behavior as a critical link between HRM practices and service quality," Hum. Resource Manage, vol. 35, no. 4, pp. 493-512, 1996.

[13] K. L. Ferguson, "Human resource management systems and firm performance," Ph.D. dissertation, College of Education and Human Development, University of Louisville, Louisville, Kentucky, 2006.

[14] G. A. Rummler and A. P. Brache, Improving Performance: How to Manage the White Space on the Organizational Chart, $2^{\text {nd }}$ ed. San Francisco, CA: Jossey-Bass, 1995.

[15] A. A. Lado and M. C. Wilson, "Human resource systems and sustained competitive advantage: A competency based perspective," Academy of Management, vol. 19, pp. 699-728, 1994.

[16] B. Becker and B. Gerhart, "The impact of human resource management on organizational performance: Progress and prospects," Academy of Management Journal, vol. 39, no. 4, pp. 779-801, 1996.

[17] J. B. Barney, "Firm resources and sustained competitive advantage," Journal of Management, vol. 17, no. 1, pp. 99-120, 1991. 
[18] E. N. Askov, "Workplace literacy: Evaluation of three model programs," Adult Basic Education, vol. 10, pp. 100-108, 2000.

[19] D. N. D. Hartog and R. M. Verburg, "High performance work systems, organizational culture and firm performance," Human Resource Management Journal, vol. 14, pp. 55-78, 2004.

[20] M. A. Huselid, "The impact of human resource management practices on turnover, productivity, and corporate financial performance," Academy of Management Journal, vol. 38, pp. 635-672, 1995.

[21] A. Oguntimehin, "Teacher effectiveness: Some practical strategies for successful implementation of universal basic education in Nigeria," African Journal of Educational Management, vol. 9, no. 1, pp. $151-161,2001$.

[22] E. S. Costea, "The challenges of human resource management towards organizational effectiveness," Journal of European Industrial Training, vol. 29, no. 2, pp. 112-134, 2005.

[23] G. Dessler, Human Resource Management, $8^{\text {th }}$ ed. NJ: Prentice-Hall, Englewood Cliffs, 2000.

[24] D. Fox, V. Byrne, and F. Roualt, "Performance improvement: What to keep in mind," Training and Development, vol. 53, no. 8, pp. 895-915, 1999.

[25] M. A. Khan, "Effects of human resource management practices on organizational performance: An empirical study of oil and gas industry in Pakistan," European Journal of Economics, Finance and Administrative Sciences, vol. 24, 2010.

[26] L. Dyer and T. Reeves, "HR strategies and firm performance: What do we know and where do we need to go," International Journal of Human Resource Management, vol. 6, no. 3, pp. 656-670, 1995

[27] B. E. Becker and M. A. Huselid, "High performance work systems and firm performance: A synthesis of research and managerial implications," Research in Personnel and Human Resource Management, vol. 16, pp. 53-101, 1998.

[28] M. Rizov and R. Croucher, "Human resource management and performance in European firms," Cambridge Journal of Economics, vol. 33, pp. 253-272, 2008.

[29] C. Sang, Relationship between HRM Practices and the Perception of Organizational Performance, Roles of Management Style, Social Capital, and Culture: Comparison between Manufacturing Firms in Cambodia and Taiwan, Tainan, Taiwan: National Cheng Kung University, 2005.

[30] V. C. Arumugam and R. Mojtahedzadeh, "The impact of human resources management practices on financial performance of Malaysian industries," International Research Journal of Finance and Economics, vol. 80, pp. 49-54, 2011.

[31] H. J. Bernadin, Human Resource Management: An Exponential Approach, $4^{\text {th }}$ ed. NewYork: McGraw-Hill Irwin, 2007.

[32] R. O. Odunlade, "Managing employee compensation and benefits for job satisfaction in libraries and information centres in Nigeria," Library Philosophy and Practice, vol. 714, 2012.

[33] J. Goodale, M. Koerner, and J. Roney, "Analyzing the impact of service provider empowerment on perceptions of service quality inside an organization," Journal of Quality Management, vol. 2, no. 2, pp. $191-215,1997$

[34] R. I. Khan, H. D. Aslam, and I. Lodhi, "Compensation management: A strategic conduit towards achieving employee retention and job satisfaction in banking sector of Pakistan," International Journal of Human Resource Studies, vol. 1, no. 1, pp. 89-97, 2011.

[35] E. N. C. Hong, L. Z. Hao, R. Kumar, C. Ramendran, and V. Kadiresan, "An effectiveness of human resource management practices on employee retention in institute of higher learning: A regression analysis," International Journal of Business Research and Management, vol. 3, no. 2, pp. 60-79, 2012.

[36] E. P. Lazear, "Salaries and piece rates," Journal of Business, vol. 59, no. 1 , pp. $405-431,1986$.

[37] B. Madrian, "Employment-based health insurance and job mobility - is there evidence of job lock," Quarterly Journal of Economics, vol. 109, no. 1, pp. 27-54, 1994.

[38] J. Gruber and B. Madrian, "Health insurance and job mobility: The effect of public policy on job lock," Industrial and Labor Relations Review, vol. 48, pp. 86-101, 1994.

[39] P. Bamberger and I. Meshoulam, Human Resource Management Strategy, Thousand Oaks, CA: Sage, 2000.

[40] J. P. McDuffie, "Human resource bundles and manufacturing performance," Industrial and Labour Relations Review, vol. 48, no. 2, pp. 197-221, 1995.

[41] S. Bhattacharya and P. Mukherjee, "Rewards as a key to employee engagement: A comparative study on I.T. professionals," ASBM Journal of Management, vol. 2, no. 1, 2009.
[42] E. J. A. Abiodun, Human Resources Management: An Overview, Shomolu, Lagos: Concept Publication, 1999.

[43] S. S. Tzafrir, "A universalistic perspective for explaining the relationship between HRM practices and firm performance at differen points in time," Journal of Managerial Psychology, vol. 21, no. 2, pp. 109-130, 2006.

[44] M. Ashar, M. M. Ghafoor, E. Munir, and S. Hafeez, "The impact of perceptions of training on employee commitment and turnover intention: Evidence from Pakistan," International Journal of Human Resource Studies, vol. 3, no. 1, pp. 74-88, 2013.

[45] E. M. Mone and M. London, Employee Engagement through Effective Performance Management: A Manager's Guide, New York: Routledge, 2009

[46] D. L. Nelson and B. L. Simmons, "Health psychology and work stress: A more positive approach," in Handbook of Occupational Health Psychology, J. C. Quick and L. E. Tetrick, Eds. Washington D.C.: American Psychological Association, 2003, pp. 97-119.

[47] P. Falcone. (2006). Preserving restless top performers: Keep your top performers engaged so they don't jump ship once job opportunities arise. HR Magazine. [Online]. Available: http://www.allbusiness.com/humanresources/workforcemanagementhi ring/8749791.html

[48] W. A. Kahn, "An exercise of authority," Organizational Behavior Teaching Review, vol. 14, no. 2, pp. 2842, 1990.

[49] W. A. Kahn, "Psychological conditions of personal engagement and disengagement at Work," Academy of Management Journal, vol. 33, no. 4, pp. 692-724, 1992

[50] F. Luthans and S. J. Peterson, "Employee engagement and manager self-efficacy: Implications for managerial effectiveness and development," Journal of Management Development, vol. 21, no. 5, pp. 376-387, 2002.

[51] F. L. Kgomo, "Employee engagement model facilitating agent retention in the contact centre industry," Ph.D. dissertation, Faculty of Management Sciences, Tshwane University of Technology, South Africa, 2010.

[52] P. Ali, "Job satisfaction characteristics of higher education faculty by race," Afr. J. Bus. Manage., vol. 4, no. 5, pp. 289-300, 2009.

[53] H. Lai, "The influence of compensation system design on employee satisfaction," African Journal of Business Management, vol. 5, no. 26, pp. 10718-10723, 2011.

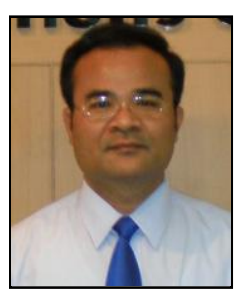

Sorasak Tangthong is a HR professional, specializing in business consulting and human resource management and strategies. He was born in Tak province, Thailand on October 2,1965 . He obtained his undergraduate degree in B.A. political science from Chiangmai University, Thailand in 1987 and then postgraduate degrees in MBA marketing and M.A. global economics and politics from the International Institution of Ramkhamhaeng University, Thailand in 1997 and 2004, and M.A. political science from Thammasart University, Thailand in 2006.

From 1987 until 2004, he had worked in various HR roles, including group HR director, senior HR manager, HR manager, recruiting manager and employee relation manager with various Multinational Organizations. Since 2004, he has been running his own HR consulting and Executive Search firm in Thailand as a managing director and senior principal. He is also a lecturer as a guest speaker at Thailand University such as Thammasart University, Naresuan University, King Mongkut Institute of Technology( KMITL), Suansunandha University and Assumption University in Thailand. His research interests are related to human resource management in Thailand's FDI manufacturing industry

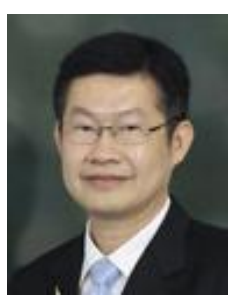

Jirasek Trimetsoontorn is an assistant professor and dean at the Administration and Management College, King Mongkut's Institute of Technology Ladkrabang in Thailand. He was born in Thailand in 1966. He obtained his undergraduate degree in B.B.A marketing from Assumption University, Thailand and then postgraduate degree in M.A. public and private management from the National Institute of Development Administration, Thailand. $\mathrm{He}$ completed his Ph.D. in marketing at the University of South Australia, Australia.

Currently, his studies include the attitude of students towards electronic learning at the King Mongkut's Institute of Technology Ladkrabang, the 
effects that knowledge and attitude of tourists in Bangkok have on ecotourism, and factors effecting the satisfaction of students in their studies of Bachelor of Science in industry management at the King Mongkut's Institute of Technology Ladkrabang. His research interests are human resource management and marketing strategic \& management field.

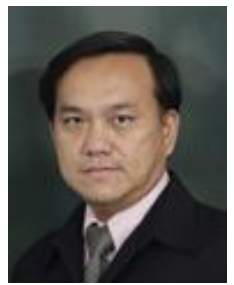

Nutthawut Rojniruntikul is an assistant professor at the Administration and Management College, King Mongkut's Institute of Technology Ladkrabang in Thailand. He was born in Thailand in 1972. He obtained his undergraduate degree in engineering at the King Mongkut's Institute of Technology Thonburi, Thailand and then postgraduate degree in M.A. business, economics and management at Chulalongkorn University, Thailand. He then completed his D.P.A. in human resource management at the National Institute of Development Administration, Thailand.
Currently, his studies include the attitude of students towards electronic learning at the King Mongkut's Institute of Technology Ladkrabang, factors effecting knowledge management at the King Mongkut's Institute of Technology Ladkrabang, and the opinions of supervisors toward the desired skills of students in their studies of Master of Science in industry management at the King Mongkut's Institute of Technology Ladkrabang. His research interests are human resource and business management. 